\title{
Еколого-ценотична характеристика популяції Hedera helix L. (Araliaceae) на території Словечансько-Овруцького кряжу
}

\section{Іван Хом'як, Олександр Гарбар, Свген Никончук, Діана Гарбар, Наталія Демчук}

Житомирський державний університет імені Івана Франка, Житомир, Україна

Адреса для листування: ecosystem_lab@ukr.net

Отримано: 10.03.19; прийнято до друку: 05.04.19; опубліковано: 28.06.19

Резюме. Моніторинг динаміки популяцій має велике теоретичне й практичне значення. Найбільший інтерес представляють популяції рідкісних видів або тих, які перебувають на межі ареалу. Такі види діагностують добре інтегровані комплексні екологічні характеристики. Вони є чутливим інструментом для моніторингу стану навколишнього середовища. Природний ареал Hedera helix уключає територію Західної Свропи та південно-західну частину Східної Свропи. Вид довгий час уважався реліктовим. Г. К. Смик пояснює диз'юнкції ареалу Hedera helix наслідком масової вирубки лісів у 20-х роках минулого століття. Нові знахідки виду на території Полісся ставлять під сумнів ці гіпотези.

Нами проаналізовано середовище існування виду, флору та рослинність у межах місцезнаходжень на території Словечансько-Овруцького кряжу. Ми використовуємо цей регіон як модельний через надзвичайно високу різноманітність оселищ і нові знахідки локалітетів Hedera helix. Ландшафтна й видова різноманітність кряжу вища, ніж на будь-якій іншій території Полісся. Матеріалами дослідження стали стандартні геоботанічні описи. Дослідження тривало з 2004 по 2018 р. Для оцінки середовища використовували метод синфітоіндикації. Антропогенну оцінку здійснювали за допомогою визначення гемеробії (антропотолерантності) угруповань за шкалою Дідуха-Хом'яка. Синфітоіндикаційний аналіз проводили з використанням програми Simargl 1.12.

Наші дослідження показали, що вид присутній в екотопах із вузькою амплітудою показників екологічних факторів. Hedera helix на території Словечансько-Овруцького кряжу трапляється в умовах стенотипних умов (перекриття 3 \% синфітоіндикаційної шкали) в екосистемах з автотрофним блоком у вигляді асоціації Stellario holosteae-Carpinetum betuli (клас Carpino-Fagetea). Однак поруч наявні території, які мають подібні екологічні умови, але чомусь не зайняті Hedera helix. Пошук відповіді на це питання потребує більш глибоких досліджень.

Ключові слова: Hedera helix, Центральне Полісся, ареал, оселище.

\section{Ecological-Cenotic Population Characteristics of Hedera Helix L. (Araliaceae) on the Territory of Slovechansko-Ovruchsky Ridge}

\section{Ivan Khomyak, Oleksandr Garbar, Yevhen Nikonchuk, Diana Garbar, Nataliia Demchuk}

Zhytomyr Ivan Franko State University, Zhytomyr, Ukraine

Correspondence: ecosystem_lab@ukr.net

Abstract. Monitoring of the population dynamics has great theoretical and practical importance. The greatest interest is the population of rare species or those on the verge of its distribution area. Rare species diagnose well integrated complex environmental characteristics. They serve as a sensitive instrument for monitoring state of the environment. The Hedera helix area includes the territory of the Western Europe and south-western part of Eastern Europe. Ivy is considered as relict plant species. Smyk G. K. explains the disjunct of the area with the detrimental effect of massive deforestation of deciduous forests in the 20 years of the last century. New findings of the Hedera helix presence on the territory of Polissya set the question about hypothetical relict status of the species.

We analyzed the habitat environment of the species, the flora and vegetation on the territory of the Slovechansko-Ovruchsky ridge. We chose this region as a model because there is the highest diversity of 
ecosystems and discovery of the new species. Here the landscape and species diversity are higher than in any other Polissya territory. The research material is standard geobotanical descriptions. The study lasted from 2004 to 2018. We used synphytoindication method to evaluate the environment. We determined anthropogenic influence on the level of hemery (anthropotolerance) of plants using the Didukh-Khomyak scale. We used the Simargl 1.12 software to calculate synphytoindication habitat.

Our studies have shown that habitat species has narrow range of environmental factors indicators. Hedera helix is located on the territory of the Slovechansk-Ovruch ridge under stenotypic conditions (3\% phytoindycation scale overlap). Hedera helix is found in ecosystems with an autotrophic unit in the form of the association Stellario holosteae-Carpinetum betuli (class Carpino-Fagetea). However, along with these habitats there are territories that have similar environmental conditions that are not occupied by Hedera helix. Finding an answer to this question requires more in-depth research.

Key words: Hedera helix, Central Polissya, area, habitat.

\section{Вступ}

Незважаючи на те, що охорона довкілля перейшла на екосистемний рівень, спостереження за станом популяцій живих організмів має велике теоретичне та прикладне значення, насамперед стосовно раритетних або малопоширених видів. 3 одного боку, такі види потребують охорони, тому зміни середовища, спричинені прямою чи опосередкованою дією людини або іншими факторами, можуть становити для них серйозну загрозу [1]. 3 іншого боку, вони краще за масові види діагностують комплексні характеристики середовища. Розмістившись на межі свого ареалу або будучи пристосованими до вузького діапазону показників факторів середовища, такі види є чутливим інструментом моніторингу стану довкілля. Це дає змогу за допомогою вивчення динаміки популяцій малопоширених видів розробляти й перевіряти динамічні моделі екосистем та створювати високоймовірнісні прогнози їх розвитку $[2,3,4]$.

Ареал Hedera helix охоплює територію, що простягається від Середземноморського узбережжя Північної Африки до Норвегії (60³2' північної широти) $[5,6]$. У широтному напрямі він охоплює території аж до Латвії, Білорусі, України, Вірменії та Ірану. Крім того, вид натуралізований i часто має статус інвазійного в Австралії, Бразилії, Канаді, Гаваї, Новій Зеландії, Індії Південній Африці та Сполучених Штатах [5].

Його східноєвропейська межа, згідно із даними, наведеними В. I. Парфеновим [7], пролягає через східне узбережжя озера Папе (Латвія), Ретовас, Среджюс, Каунас (Литва), Щучин, Жарковщину, Бєлий Лєсок, Ясень, Старе Роматово (Білорусь) Любомль, Ковель, Задиби, Рівне, Городець, Високу Піч, МогилівПодільський (Україна), Сороки, Калараш, Злоті (Молдова). Дослідження указують на зміщення межі ареалу далі на схід від Городця до Черевок і від Високої Печі до околиць Києва $[8,9]$.
В Україні він часто трапляється в листяних лісах Карпатських гір та їхніх передгір'ях, а також на західній частині Подільської височини. На решті території його ареал диз'юнктивний, досягає на сході до Середнього Подніпров'я й на північному сході до СловечанськоОвруцького кряжу $[1,10,11,12,13]$. Серед описаних локалітетів є такі, де Hedera helix знаходять протягом тривалого часу $[1,13]$. Однак зафіксовано випадки зникання відомих ділянок, а також їх появи на нових територіях $[8,9,14]$.

Г. К. Смик вважав, що раніше плющ мав більш масове поширення територією Полісся [12]. Він пояснює значну диз'юнкцію ареалу згубним впливом масових вирубок листяних лісів у 20-ті роки минулого століття. Також Г. К. Смик, як і більшість його сучасників, був прихильником ідеї реліктовості цього виду [15]. Дійсно, вид на території Східної Свропи відомий із відкладень від верхньокрейдяних до пліоценових $[15,16]$. Його екологічний спектр несумісний 3 умовами, які склалися під час останнього зледеніння. Однак нові знахідки та активне поширення в Новому Світі ставлять під сумнів цю гіпотезу. У межах відомих локалітетів Hedera helix на території Полісся поширюється лише за рахунок вегетативного розмноження $[8,9]$. Це унеможливлює його розповсюдження на нові території протягом короткого часу. Більш імовірно, що рослина була перенесена із суцільного ареалу на Заході України орнітохорним способом. Саме на такий спосіб поширення Hedera helix указують численні дослідження по всьому світу [17]. Крім того, знахідки рослини в лісових масивах віком від 50 до 80 років свідчать про те, що вирубка, на яку вказував Г. К. Смик, не змогла $б$ настільки сильно фрагментувати первинний суцільний ареал [8].

Найбільш імовірною $є$ гіпотеза, згідно 3 якою плющ поширюється птахами, пов'язаними із широколистяними лісами (наприклад Turdus merula L.), але утворює стійкий локалітет лише в тому випадку, коли насіння 
Еколого-иенотична характеристика популящіï Hedera helix L. (Araliaceae) на територіï Словечансько-Овручького кряжу

потрапляє в сприятливі природні умови. Якщо воно пройшло через травну систему птахів, то має схожість, близьку до $100 \%$, тоді як посаджене в плодах - лише $60 \%$. Сушіння плодів пов-ністю вбиває насіння [18]. Потрібно зауважити, що плодоношення плюща на території Полісся - рідкісне явище, оскільки рослини щороку обмерзають i мусять відновлювати свою вегетацію від поверхні грунту. Вегетативне поширення відбувається поступово від центру проростання. Розриви ареалу, які досягають десятків кілометрів, виключають можливість такого способу поширення. Отже, версія про орнітохорне розповсюдження плюща залишається головною [19]. Для перевірки цієї гіпотези треба провести двохетапні дослідження. На першому етапі потрібно вивчити еколого-ценотичні умови оселищ 3 участю Hedera helix, на другому провести популяційно-генетичні дослідження організмів із різних частин ареалу задля встановлення рівня їх спорідненості та філогеографічних особливостей. У цій статті розглянуто результати першого етапу дослідження.

\section{Матеріали й методи досліджень}

Матеріалами дослідження $є$ стандартні геоботанічні описи [20], зроблені в локалітетах Hedera helix у період із 2004 по 2018 p. Оскільки у 2018 р. описано нове місцезнаходження виду на території СловечанськоОвруцького кряжу, на ділянці, де, згідно 3 описами 2005 і 2009 р., вид не фіксували, то саме цю територію обрано як модельну.

Для оцінки середовища використано метод синфітоіндикації із застосуванням уніфікованої шкали Дідуха-Плюти [21]. Антропогенний вплив оцінювали за рівнем гемеробії (антропотолерантності) угруповань за шкалою Дідуха-Хом'яка [3, 22]. Показник динаміки встановлювали відповідно до оригінальної методики оцінки динаміки за величиною надземної фітомаси та іiі віку [2, 4]. Для обрахунків синфітоіндикаційних даних застосували програму Simargl 1.12 [23]. Статистичну обробку даних виконували за допомогою пакета програм «STATISTICA 6.0».

\section{Результати й обговорення}

На території Словечансько-Овруцького кряжу виявлено три місцезнаходження Hedera helix. Два 3 них давно відомі та багаторазово описані [10]. Це територія заказника «Плющ» (кв. 8, вид. 15; кв. 13, вид. 6. Городецьке лісництво, ДП «Словечанське ЛГ») та урочища «Полом'я» (кв. 40, Усівське лісництво, ДП «Словечанське ЛГ»). У 2017 р. знайдено й описано нове місцезнаходження в 3 кварталі Велідницького лісництва (ДП «Словечанське ЛГ») за координатами $51^{\circ} 18^{\prime} 26.8^{\prime \prime} \mathrm{N} 28^{\circ} 22^{\prime} 09.8^{\prime \prime} \mathrm{E}$.

Відкрита нещодавно ділянка 3 Hedera helix розміщена на південній частині кряжу. Висота місцевості - 230 м. н. р. м. Грунти дерновопідзолисті легкосуглинисті. Під грунтом містяться значні залягання рожевого кварциту. У деяких місцях спостерігаємо вихід кристалічних порід на поверхню.

Лісовий масив $є$ похідним після вирубки в післявоєнні роки старого дубово-грабового насадження. Виходячи 3 аналізу створених геоботанічних описів, тип лісу - свіжа діброва (D2). Вік дерев - близько 40-60 років. Середній діаметр стовбура - 30 см, зімкненість крон 85 \%. У флорі деревного ярусу переважають Carpinus betulus L. (до 50 \%) та Populus tremula L. (25 \%). Також присутні Quercus robur L., Acer platanoides L., Pinus sylvestris L., Betula pendula Roth. Підлісок утворений негустими заростями Sorbus aucuparia L. і Frangula alnus Mill. Трав'яна рослинність досить розріджена, за винятком Hedera helix, який покриває понад $50 \%$ досліджуваної ділянки. Крім нього, у трав'яному покриві велику площу займає Polygonatum odoratum (Mill.) Druce (більше ніж 25 \%). Решта видів має дуже низьке проективне покриття. Моховий ярус, який складається переважно 3 Polytrichum commune Hedw., малопотужний - до $10 \%$.

Флора й рослинність типові для кварцитної частини кряжу, яку віднесено до ЧервонськоГородецького району ацидофільних скельнодубових i дубових лісів Центрального (Житомирського) Полісся [24]. Флору нового місцезнаходження складають 18 видів, тоді як для всіх трьох відомо 26 видів. Лише в новому місцезнаходженні трапляються Polygonatum odoratum, Acer platanoides, Primula veris L., Carex brizoides L., Frangula alnus, Populus tremula, Dryopteris filix-mas (L.) Schott., Milium effusum L. та Polytrichum commune. Разом із тим тут відсутні Viola odorata L., Quercus robur L., Euonymus verrucosa Scop., Oxalis acetosella L., Rubus caesius L., Athyrium filix-femina (L.) Roth. Водночас тут немає Viola odorata L., Majanthemum bifolium (L.) F. W. Schmidt i Rubus caesius L., які трапляються у двох старих локалітетах. 3 одного боку, нове місцезнаходження можна вважати більш флористично багатим, оскільки тут присутні 69 \% флори 
ценозів Словечансько-Овруцького кряжу, тоді як інші ділянки містять 42 та $54 \%$ відповідно. 3 іншого боку, кількість видів на території нового місцезнаходження дорівнює чисельності видів на території попередніх разом узятих.

Рослинні угруповання належать до одного варіанта Stellario holosteae-Carpinetum betuli Oberdorfer 1957 var. Hedera helix, союзу Carpinionbetuli Issler 1931, порядку Fagetalia sylvaticae Pawl 1928, класу Carpino-Fagetea Jakucsex Passarge 1968.

Фітоценотична однотипність указує на екотопічну однорідність (табл. 1). Частка перекриття шкали для всіх трьох локалітетів коливається від 1 до $8 \%$ за середнього значення 3 \%. Найбільші коливання властиві для показника освітленості, а найменші - для загального сольового режиму, омборежиму та континентальності. Нове місцезнаходження має показник освітленості на 1,31 бала вищий, ніж старі. Антропогенна трансформація екосистем досліджуваних оселищах помірна (мезогемеробні), що характерно для типових середньовікових лісових масивів Полісся. У той час, коли в межах заказника «Плющ» упроваджено відповідний природоохоронний режим, то в межах нового локалітету відпрацьовуються стандартні для такого типу насаджень лісотехнічні процедури. Потрібно зауважити, що при цьому рівень антропогенної трансформації не змінився й відхиляється лише на 0,5 \%.

Статистична обробка даних синфітоіндикаційного аналізу вказує на те, що екотопи, заселені Hedera helix, належать до мезофітних, гемігідроконтрастофобних, субацидофільних, мезотрофних, акарбонатофільних, гемінітрофільних, геміарофобних, геміокеанічних, субкріофітних, мезогемеробних. Динамічні показники відповідають сукцесійній стадії стиглих корінних лісів [25]. За присутністю певних елементів флори можна стверджувати, що ці насадження нещодавно перейшли до такої стадії й ще не втратили всіх ознак відновлення лісу Природна та антропогенна динаміка оселищ Hedera helix характерна для великих площ лісових масивів Українського Полісся. Це вказує на існування потенціалу для розселення виду.

Порівняння нового місцезнаходження 3 двома попередніми вказує на велику кількість спільних рис. Це стосується, насамперед, умов середовища, флористичного оточення та належності до певного рослинного угруповання. Показники факторів середовища коливаються незначною мірою (табл. 2). За винятком режиму освітленості, вони не перевищують 1 бал за уніфікованою шкалою Дідуха-Плюти. На території заказника «Плющ» найнижчі показники багаторічного режиму зволоження й найближчі до оптимуму дані мікроклімату, але за хімічним складом грунту вони займають проміжне становище. Можна стверджувати, що саме в межах створеного заказника найсприятливіші умови середовища для існування виду, а в межах нового локалітету найбільш віддалені від оптимуму, порівняно iз іншими.

Таблиия 1

\section{Статистичні характеристики фітоіндикаційних показників факторів середовища місцезнаходжень на території Словечансько-Овруцького кряжу}

\begin{tabular}{|c|c|c|c|c|c|c|c|c|c|c|c|c|c|c|}
\hline \multirow{2}{*}{ 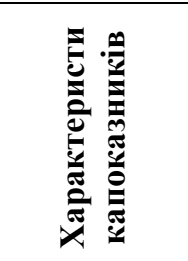 } & \multicolumn{14}{|c|}{$\begin{array}{c}\text { Показники факторів середовища } \\
\text { (балів за уніфікованою шкалою Дідуха-Плюти) }\end{array}$} \\
\hline & HD & FH & RC & SL & CA & NT & $\mathbf{A E}$ & TM & OM & $\mathbf{K N}$ & CR & LC & HE & ST \\
\hline Середнє & 11,96 & 4,98 & 7,42 & 6,25 & 6,62 & 5,77 & 6,91 & 8,82 & 13,68 & 7,74 & 8,80 & 4,92 & 6,35 & 14,95 \\
\hline Мінімум & 11,71 & 4,90 & 7,21 & 6,20 & 6,34 & 5,46 & 6,71 & 8,59 & 13,62 & 7,66 & 8,57 & 4,64 & 6,23 & 14,65 \\
\hline Максимум & 12,17 & 5,08 & 7,66 & 6,32 & 6,76 & 6,00 & 7,26 & 8,95 & 13,78 & 7,89 & 8,95 & 5,33 & 6,53 & 15,33 \\
\hline Амплітуда & 0,46 & 0,18 & 0,45 & 0,12 & 0,42 & 0,54 & 0,55 & 0,35 & 0,16 & 0,23 & 0,38 & 0,69 & 0,30 & 0,68 \\
\hline $\begin{array}{l}\text { Перекриття } \\
\text { шкали }\end{array}$ & 0,02 & 0,02 & 0,03 & 0,01 & 0,03 & 0,05 & 0,04 & 0,02 & 0,01 & 0,01 & 0,03 & 0,08 & 0,02 & 0,03 \\
\hline
\end{tabular}

Примітка. Фактори середовища: HD - багаторічний режим зволоження, FH - змінність зволоження, $R C$ - кислотність, $S L$ - загальний сольовий режим, $C A-y$ міст карбонатів, NT-yміст доступного нітрогену, AE - аерація грунту, TM - терморежим, ОМ - омборежим, КN континентальність, CR - кріорежим, LC - освітленість, HE - антропогенний вплив, ST фітоіндикачійний показник динаміки. 
Еколого-ценотична характеристика популящіï Hedera helix L. (Araliaceae) на територї Словечансько-Овруиького кряжу

Таблиия 2

Показники факторів середовища місцезнаходжень на території СловечанськоОвруцького кряжу

\begin{tabular}{|c|c|c|c|c|c|c|c|c|c|c|c|c|c|c|}
\hline \multirow{2}{*}{ 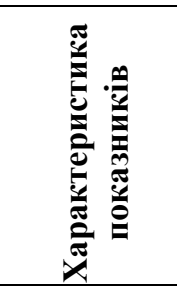 } & \multicolumn{14}{|c|}{$\begin{array}{c}\text { Показники факторів середовища } \\
\text { (балів за уніфікованою шкалою Дідуха-Плюти) }\end{array}$} \\
\hline & HD & FH & RC & SL & CA & NT & $\mathbf{A E}$ & $\mathbf{T M}$ & OM & $\mathbf{K N}$ & CR & $\mathbf{L C}$ & HE & ST \\
\hline $\begin{array}{l}\text { Заказник } \\
\text { «Плющ» }\end{array}$ & 11,71 & 5,08 & 7,39 & 6,32 & 6,76 & 5,84 & 6,71 & 8,95 & 13,63 & 7,66 & 8,95 & 4,79 & 6,53 & 15,33 \\
\hline $\begin{array}{l}\text { Урочище } \\
\text { «Полом’я» }\end{array}$ & 12,00 & 4,90 & 7,66 & 6,24 & 6,34 & 6,00 & 6,76 & 8,92 & 13,78 & 7,66 & 8,88 & 4,64 & 6,30 & 14,87 \\
\hline Черевки & 12,17 & 4,96 & 7,21 & 6,20 & 6,75 & 5,46 & 7,26 & 8,59 & 13,62 & 7,89 & 8,57 & 5,33 & 6,23 & 14,65 \\
\hline
\end{tabular}

Незважаючи на вузьку екологічну амплітуду оселищ 3 участю Hedera helix, дослідження екосистем широколистяних лісів асоціації Stellario holosteae-Carpinetum betuli на території Правобережного Полісся вказують на те, що існує велика кількість екотопів, придатних для заселення цим видом. Однак на сьогодні відома лише невелика кількість знахідок цього виду на території Полісся, як-от: для Центрального Полісся - лише п'ять знахідок [1, 10, 12, 14], а для Київського - два $[9,11]$. Постає природне запитання: чому не відбувається масового поширення цього виду в ідентичні екотопи? Більше того, у суцільних однотипних масивах вид не займає всю однорідну площу, а $\epsilon$, по суті, великою куртиною чи групою куртин.

Виходячи з вищесказаного, можна висунути кілька гіпотез. По-перше, поширенню заважають кліматичні умови, коли низькі температури взимку знищують молоді пагони, що плетуться деревами. Через це тут не вдається зафіксувати цвітіння й плодоношення. Появу нових місцезнаходжень можна було б пояснити змінами клімату, коли через глобальне потепління на території Полісся формуються умови для поширення виду орнітохорним способом із місцевих локалітетів. По-друге, може існувати невизначений нами чинник середовища, який обмежує поширення Hedera helix. По-третє, можливо, проникнення цього виду на територію Полісся відбувається лише орнітохорним способом 3 основного ареалу. Остання версія виглядає найбільш імовірною. Для іiі підтвердження, а також для перевірки інших гіпотез потрібно провести популяційно-генетичні дослідження та встановити, із якою 3 популяцій мають найбільшу спорідненість особини, знайдені в новому місцезнаходженні.

\section{Висновки}

Hedera helix міститься на території Словечансько-Овруцького кряжу в стенотопних умовах (середнє перекриття фітоіндикаційної шкали - 3 \%) екосистем 3 автотрофним блоком у вигляді асоціації Stellario holosteae-Carpinetum betuli (клас Carpino-Fagetea).

За синфітоіндикаційними показниками екотопи, заселені Hedera helix, належать до мезофітних, гемігідроконтрастофобних, субацидофільних, мезотрофних, акарбонатофільних, гемінітрофільних, геміарофобних, геміокеанічних, субкріофітних, мезогемеробних із динамічними показниками, що відповідають сукцесійній стадії стиглих корінних лісів.

Оскільки, наявні на території кряжу екотопи 3 умовами, ідентичними до місцезростання Hedera helix, не заселяються цим видом, то потрібно більш глибоко й усебічно проаналізувати умови зростання та поширення Hedera helix на території Полісся. Основними гіпотезами $є$ те, що перешкодою до масового поширення $\epsilon$ невідповідність кліматичних умов для повного циклу розвитку рослини. Мозаїчність оптимальних едафічних умов та орнітохоний спосіб поширення призводять до вираженої диз'юнкції поліської частини ареалу.

\section{Література}

1. Мельник, В. І.; Баранівський, О. Р.; Харчишин, В. Т.; Хом'як, І. В.; Корнійчук, В. С.; Тітова О. Т. Флористичні знахідки на Житомирському Поліссі. Інтродукція рослин; 2009, 2, с 3-8.

2. Хом'як, I. В. Фітоіндикаційний аналіз ступеня трансформації екосистем Центрального Полісся. Питання біоіндикаиії та екологї̈; 2012, 17 (1), c 3-11. 
3. Хом'як, I. В.; Демчук, Н. С.; Василенко, О. М. Фітоіндикація антропогенної трансформації екосистем на прикладі Українського Полісся. Екологічні науки; 2018, 3 (22), с 113-118.

4. Khomiak, I.; Onishchuk, I.; Demchuk, N. Phytoindicators of ecosystem dynamics in Ring-banc Ukrainian Polissia. Science Rise: Biological Science; 2018, 4 (13), p 25-30. DOI: 10.15587/25198025.2018.141170.

5. Grivet, D.; Petit, R. J. Phylogeography of the common ivy (Hedera sp.) in Europe: genetic differentiation through space and time. Molecular ecology; 2002, 11 (8), c 1351-1362. DOI: 10.1046/j.1365-294X.2002.01522.x.

6. Ellenberg, H. Vegetation Ecology of Central Europe. 4th Ed. Cambridge - New York - New Rochelle - Melbourne — Sydney, Cambridge University Press, 1988. 731 p.

7. Парфенов, В. И. О естественном произрастании Hedera helix L. в Белоруссии. Ботаника; 1967, IX, с 101-105.

8. Никончук, С. В. Особливості динаміки Hedera helix L. (Araliaceae) на території Словечансько-Овруцького кряжу. Проблеми та перспективи розвитку теорії екосистем: збірник наукових праць; Житомир: ЖДУ, 2018, с 29-32.

9. Красняк, О. І., Тищенко, О. В. Hedera helix L. (Araliaceae) на території національного природного парку «Голосіївський». Український ботанічний журнал; 2009, 66 (1), с 25-28.

10. Барбарич, А. І. Флора і рослинність Полісся Української РСР. Нариси про природу $i$ сільське господарство Українського Полісся; Видавництво Київського ун-ту, Київ: 1955, с 269-321.

11. Рогович, А. С. Обозрение семенных и высших споровых растений, входящих в состав флоры губерний Киевского учебного округа: Волынской, Подольской, Киевской, Черниговской и Полтавской. [Киевские] Универ. Известия; 1896, 7, c 297-308.

12. Смик, Г. К. О реликтовых растениях Овручско-Словечанского кряжа. Природная обстановка и фауны пришлого; Киев; Наукова думка: 1965, с 162-165.
13. Смик, Г. К. Плющ звичайний (Hedera helix L.) на Словечансько-Овруцькому кряжі. Укр. ботан. журн.; 1965, 22 (2), с 102-104.

14. Таргонський, П. Н.; Примак, М. Б. Нове місцезростання Hedera helix L. на Житомирському Поліссі. Укр. ботан. Журн; 1980, 37 (1), 94 с.

15. Котов, М. І. Родина Аралійові - Araliaceae Vent. У кн.: Флора УРСР; Вид-во АН УРСР, Київ: 1955, 7, с 459-460.

16. Клоков, М. В. Основные этапы развития равнинной флоры Европейской части СССР. Материаль по истории флоры и растительности СССР; М.; Л. : Изд-во Наука, 1963, 4, с 377-406.

17. Snow, Barbara; Snow, David. Birds and berries: A study of ecological interaction. Staffordshire, UK: T. \& A. D. Poyser, 1988, 268 p.

18. Clergeau, Philippe. The effect of birds on seed germination of fleshy-fruited plants in temperate farmland. Acta Oecologica; 1992, 13 (6), c 679-686.

19. Metcalfe, Daniel L. Biological flora of the British Isles: Hedera helix L. Journal of Ecology; 2005, 93 (3), c 632-648. DOI:10.1111/j.13652745.2005.01021.x.

20. Миркин, Б. М.; Наумова, Л. Г.; Соломещ, А.И. Современная наука о растительности; М.: Логос, 2001, с 99-106.

21. Дідух, Я. П.; Плюта, П. Г. Фітоіндикація екологічних факторів; К., 1994, 280 с.

22. Дідух, Я. П.; Хом'як, І. В. Оцінка енергетичного потенціалу екотопів залежно від ступеня їх гемеробії на прикладі СловечанськоОвруцького кряжу. УБЖ; 2007, 1, с 235-243.

23. Хом'як, І. В.; Хом'як, Д. І. Нова програма екосистемологічного моніторингу «SIMARGL». Сучасні проблеми екології та геотехнологій; Житомир, Видавництво ЖДТУ, 2012, с 76.

24. Хом'як, І. В. Особливості територіальної диференціації екотопів лісових формацій Словечансько-Овруцького кряжа. К.: Український ботанічний журнал: 2006, 2, с 235-243.

25. Хом'як, I. В. Фітоіндикаційний аналіз передклімаксичних стадій розвитку екосистем. Питання біоіндикації та екологї̈; 2013, 18 (1), c 20-29. 